\title{
The Effect of Foreign Direct Investment on Economic Growth: Evidence from South Africa
}

\author{
Adrino Mazenda \\ PhD Candidate, Department of Economics, University of Fort Hare \\ Email: amazenda@gmail.com
}

\section{Doi:10.5901/mjss.2014.v5n10p95}

\begin{abstract}
Foreign direct investment amongst other mechanisms provides capital inflow meant to stimulate economic growth. Apart from promoting economic growth, FDI can also lead to increase in employment, technology, technical knowhow and managerial skills. South Africa has implemented various policy initiatives in attempts to attract foreign investment. This study investigates on the effect of foreign direct investment on economic growth, with particular reference to the South African economy. The period of study is from 1980 to 2010. Johansen cointegration and Vector Error Correction Modelling (VECM) framework where utilised as estimation techniques. Variables specified in the methodology include real gross domestic product (RGDP), foreign direct investment (FDI), domestic investment (INVE), real exchange rate (REXCH) and foreign marketable debt (DEBT). The long run results showed that FDI, REXCH and DEBT have a negative impact on growth. INVE has a positive impact on growth. The impulse response and variance decomposition analysis complemented the long and short-run findings. Conclusions and policy recommendations were made using these results.
\end{abstract}

Keywords: Foreign direct investment, Economic growth, South Africa

\section{Introduction and Background of Study}

Over the past decade, many developing countries around the world have experienced substantial growth in their economies, with even faster growth in international transactions, especially in the form of foreign direct investment (FDI) (WIR, 2011). The net share FDI of World Gross Domestic Product (GDP) has grown more than five times in the nineties and early $20^{\text {th }}$ century, making the causes and consequences of FDI and economic growth a subject of ever-growing interest (WIR, 2011:44).

The effects of FDI from the viewpoint of the target country have been examined thoroughly, but the empirical results are contradictory. Foreign direct investment (FDI) as transmitted by the multinational corporations has several welfare implications, one of which is the effect of FDI on economic growth of the recipient country. On one hand, if FDI has a positive impact on economic growth, then the host country should encourage FDI flows by offering tax incentives, infrastructure subsidies, import duty exemptions and other measures to attract FDI. On the other hand, if FDI has a negative impact on economic growth, then a host country should take precautionary measures to discourage and restrict such capital flows (Lyroudi, Papanastasiou, and Vamvakidis, 2004:99).

According to Carkovic and Levine (2002) Firm- level studies of specific countries often find that FDI does not boost economic growth, and in retrospect, there is no evidence of a positive technology spill-over from foreign firms to domestically owned firms. In contrast, macro-economic studies on growth and FDI often confirm positive evidence on the notion that FDI enhances growth, and leads to positive technology spill-over from foreign to domestic firms, however these results must be viewed sceptically since they do not fully control for simultaneity bias, country specific effects, and the routine use of lagged dependent variables in growth regressions (Carkovic and Levine, 2002:2).

Numerous studies have investigated the determinants of economic growth in South Africa, including the contribution of aggregate investment expenditure. Few have addressed the distinction between domestic and foreign investment expenditure on long run development and on economic growth (Fedderke and Romm, 2004).

According to Borensztein, Gregorio and Lee (1998:120), foreign direct investment in South Africa has tended to be capital intensive with determinants resulting from the net rate of return as well as the risk profile of the foreign direct investment liabilities. Borensztein et al, (1998:120) further reiterate that theoretical and empirical literature suggests the advent of policy and non- policy factors as drivers of foreign direct investment. Non-policy factors include market size, distance factor proportions, political and economic stability. Policy factors include openness to trade, product market regulation, labour market arrangements, corporate tax rates and infrastructural development (Borensztein, et al, 
1998:121).

The growth structure in South Africa has shifted from factor accumulation to efficiency gains as measured by total factor productivity. Thus technology and skills transfer assume great importance as spill-over from foreign direct investment (Fedderke and Romm, 2005:180). Unemployment is the major impediment to the realization of growth prospects with 24 per cent of the economically active in South Africa being unemployed by June 2010 (Stats SA, 2010). In order to address the unemployment problem as well as economic growth, the government established a number of macroeconomic policies, namely RDP, GEAR, ASGISA and NGP. These macroeconomic policies have a common thread in theme of employment creation and growth. Nevertheless the growth prospects as envisaged in these policies have not been realised to the full in South Africa. In order to boost economic growth as well as employment creation in South Africa, foreign direct investments are necessary.

Xavier (1994:15) argues that suitable factors of production, supportive government incentives and managerial expertise enhance the chance of attracting foreign direct investment. He further asserts that aspects such as infrastructure, government support, firm strategy and customer demand prove to be important elements in the location of industries and economic growth. Thus an improved understanding of the determinants of portfolio capital flows as well as foreign direct investment flows should prove useful in lifting restrictions on capital movements.

\section{Literature Review}

Empirical literature from varying countries in different stages of development produces varying results on the effect of foreign direct investment on economic growth. The results are based on factors such as the degree of substitution between domestic and foreign investment patterns, and other country's specific characteristics.

Pradhan (2011) explored on the role of FDI on the trade- led growth hypothesis in three counties, namely Australia, Canada and Israel for the period 1965-2009. The study was based on panel cointegration and causality tests. The results show long-run cointegration relationship of FDI and growth after allowing for heterogeneous country effect. The causality test confirms the presence of long-run and short-run bi-directional causality between openness and economic growth. It also confirms the presence of unidirectional causality from economic growth to FDI, but not vice versa. At individual level, FDI was found to cause economic growth on Australian economy only. The conclusion was that economic growth may harm openness and foreign direct investment in the three countries investigated.

Louzi and Abadi (2011) used FDI-led growth hypothesis in testing the effect of foreign direct investment on economic growth in Jordan. The vector error correction approach from 1990-2009 time series data was used to generate an econometric model that captures two way linkages between variables of interests. Results from the study show that FDI inflows do not exert an independent influence on economic growth.

Sridharan, Vijayakumar and Chandra (2009) studied the causal relationship between Foreign Direct Investment and Growth in the BRICS countries (Brazil, Russia, India, China and South Africa). The study used quarterly data from 1996 to 2007 for Brazil, 1994 to 2007 for Russia, 1992 to 2007 for India, 1999 to 2007 for China and 1990 to 2007 for South Africa. The study employs the Industrial Production Index (IPI) as a measure of economic growth. Johansen's cointegration model and vector error correction model (VECM) were used as estimation techniques. The empirical results found that Growth leads to FDI bi-directionally for Brazil, Russia and South Africa and FDI leads Growth uni-directionally for India and China respectively.

Jyun-Yi and Hsu (2008) examined the effect of foreign direct investment on economic growth. Threshold regression techniques developed by Caner and Hansen (2004) formed the basis of the study. The sample of the study covers 62 countries from both the developing and developed world for the period from 1975 - 2000. Initial GDP, human capital and the volume of trade were used as threshold variables. Under the threshold regression, initial GDP and human capital were found to be important factors in explaining FDI. FDI was found to have a positive and significant impact on growth when host countries have better levels of initial GDP and human capital.

Khaliq and Noy (2007) investigate the impact of foreign direct investment on economic growth using detailed sectoral data for FDI inflows to Indonesia over the period 1997-2006. Using the methodology of augmented production function specification and regression methodology with time fixed effects, they concluded that in the aggregate level, FDI has a positive effect on economic growth. However, when accounting for the different average growth performance across sectors, the beneficial impact of FDI was considered to be no longer apparent. When examining different impacts across sectors, estimation results showed that the composition of FDI matters for its effect on economic growth. Few sectors reflected a positive impact of FDI and one sector even showed a robust negative impact of FDI on economic growth.

Moolman et al, (2006) investigated the macroeconomic link between foreign direct investment in South Africa, and 
its resultant impact on potential output. Cointegration techniques and time series data from 1970 to 2003 were utilized to construct a model suitable for policy analysis. Five variables were explored as explanatory variables for FDI in the model. They include real exchange rate, with the rand-dollar exchange, real GDP as a measure of market size, infrastructure, openness to trade and a dummy variable of sanctions. Empirical results indicated that market size, openness and infrastructure are factors on which South African policy makers should focus when seeking to attract foreign direct investment. Thus also in this regard, there was found to be positive and significant results on the effect of FDI on economic growth.

Fedderke and Romm (2004) studied growth impact and determinants of Foreign Direct Investments in South Africa using the vector error correction model. The primary objective of the study was to provide a structural analysis of the growth impact of FDI in South Africa and its determinants. The study used aggregate time series data in South Africa for the period 1960 to 2002. The empirical results show that growth impact of FDI is positive in South Africa, thus confirming the positive spill-over effect of foreign capital on output in South Africa. While there is a crowd-out of domestic investment from foreign direct investment, this impact is restricted in the short run.

Using cross-section regression for 71 developing countries, Alfaro, Chanda, Ozcan, and Sayek, (2006) examined whether economies with well- developed financial markets are able to benefit and increase their economic growth with the attraction of FDI. They argued that the lack of development of the domestic financial markets can reduce the domestic economy's ability to benefit from potential FDI spill-overs. Data from IMF "Financial Statistics" (2000) was used for net FDI inflows. For economic growth, growth rate of output measured as the growth of real per capita GDP in constant US dollars was used. The data was obtained from World Development Indicators (2000). A calibration exercise was contacted between theoretical and empirical literature. The results indicated that in most of the 71 developing countries in the sample, FDI had a negative effect on economic growth. Thus confirming their hypothesis that insufficiently developed financial markets and institutions can diminish the positive effects of FDI.

The studies mentioned above are from different countries, uses different techniques but the variables used in their respective empirical models are similar. Empirical literature done by Fedderke and Romm, (2004) and Moolman et al, (2006) provides an empirical framework adopted in the study.

\section{Methodology}

The theoretical framework which underpins the methodology is based on the endogenous growth model. The model assumes that labour, human capital, physical capital as well as technological change are primary sources of growth. An augmented production function is employed in deriving the empirical model. The production function is presented as follows:

$$
Q=A L^{\alpha} K^{\beta}
$$

Where:

$Q=$ Total production (the monetary value of all goods produced in a year)

$L=$ Labour input

$K=$ Capital input

$A=$ Total factor productivity

$\alpha$ and $\beta$ are output elasticity for labour and capital, respectively. These values are constants determined by available technology. Output elasticity measures the responsiveness of output to a change in levels of either labour or capital used in production.

For example if $\alpha=0.15$, a $1 \%$ increase in labour would lead to approximately a $0.15 \%$ increase in output. If $\alpha+\beta=$ 1 , the production function has constant returns to scale. That is, if $L$ and $K$ are each increased by $10 \%, Y$ increases by $10 \%$. Thus $\alpha+\beta<1$ implies that returns to scale are decreasing. If $\alpha+\beta>1$ returns to scale are increasing.

Romer (1993:81) asserts that, if it is assumed that the number of researchers producing knowledge is constant, the model will predict that all growth is due to technological progress. That is to say the capital-labour $(K / L)$ ratio, the stock of knowledge and output, all grow at a constant rate. Without technical progress, there will be no growth.

The underlying model will be modified by employing real GDP growth as the dependent variable as a function of foreign direct investment (FDI), Domestic Investment (INVE), Real Exchange Rate (EXCH) and Foreign Debt (DEBT).

This can be written as follows:

$\operatorname{RGDP}_{\mathrm{t}}=\mathrm{f}\left(\mathrm{FDI}_{\mathrm{t}}, \mathrm{INVE}_{\mathrm{t}}, \mathrm{REXCH}_{\mathrm{t}}, \mathrm{DEBT}_{\mathrm{t}}\right)$

Where:

RGDP $_{\mathrm{t}}=$ Real Gross Domestic Product in year $\mathrm{t}$

$\mathrm{FDI}_{t}=$ Foreign Direct Investment in year $\mathrm{t}$ 
$\operatorname{INVE}_{t}=$ Domestic Investment in year $\mathrm{t}$

$\mathrm{REXCH} \mathrm{t}_{\mathrm{t}}=$ Real Exchange Rate in year $\mathrm{t}$

DEBT ${ }_{t}=$ Foreign Debt in year $\mathrm{t}$

The model to be estimated is expressed in logarithms as follows:

$\log R G D P P_{t}=\log \left(\beta_{0}+\beta_{1} \mathrm{FDI}_{t}+\beta_{2}\right.$ INVE $\left._{t}+\beta_{3} R E X C H_{t}+\beta_{4} \mathrm{DEBT}{ }_{t}+\varepsilon_{t}\right)$

Where $\beta_{1}, \beta_{2}, \beta_{3}$ and $\beta_{4}$ are the coefficients to be estimated and $\varepsilon_{t}$ is the error term. The error term represents the influence of the omitted variables in the construction of the data.

In employing measures on the effect of FDI on economic growth, the aim is to use proxies that have been used in most FDI literature, particularly in South Africa. Studies done by Fedderke and Romm, (2004) and Moolman et, al, (2006) provided the base model. The base model was then extended by adding variables for which there was data.

The Augmented Dickey-Fuller (ADF) and Phillips Perron (PP) tests were used to test for stationarity in this study.

Following was the cointegration test using the Vector Error Correction Models (VECM) technique developed by Johansen (1990) and Juselius (1995).

Diagnostic tests which include heteroscedasticity, residual normality and auto-correlation were performed on the model. Finally impulse response and variance decomposition analysis were undertaken to determine the responsiveness and movement in dependent variable due to shocks from independent variables.

\section{Estimation and Analysis of Results}

\subsection{Unit Root Tests}

The cointegration test among the variables that are used in the model requires the existence of a unit root for each variable. A preliminary test for unit root is first carried out using the graphical method. The rationale is to check the properties of time series data. Graphical plots in Figure 5.1(a) suggest that the variables LRGDP, LFDI, LINVE and LDEBT seem to be trending upwards while LREXCH does not show a clear trend as it fluctuates over time. All of the series seem to be exhibiting a time varying mean and variance suggesting that they are non- stationary in levels.

The Augmented Dickey- Fuller (ADF) and Phillips Perron (PP) tests were conducted to reinforce the graphical analysis findings. The results of the ADF and PP tests are presented in Table 4.1.

Table 4.1 ADF and PP Test Results

\begin{tabular}{|c|c|c|c|c|c|c|c|}
\hline & & \multicolumn{3}{|c|}{ Augmented Dickey-Fuller } & \multicolumn{3}{|c|}{ Phillips-Perron } \\
\hline Order of integration & variable & intercept & Trend and intercept & None & intercept & Trend and intercept & None \\
\hline Level & LRGDP & 1.791 & -1.167 & $2.665^{\star \star \star}$ & $2.291^{*}$ & -0.535 & $5.092^{\star \star \star}$ \\
\hline $1^{\text {st }}$ diff & DRGDP & -2.591 & $-3.822^{\star *}$ & -1.517 & $-3.297^{\star *}$ & $-4.465^{\star \star \star}$ & $-2.198 * *$ \\
\hline Level & LFDI & 2.492 & 0.258 & $3.432^{\star \star \star}$ & $2.668^{*}$ & 0.151 & $3.938 * \star \star$ \\
\hline $1^{\text {st }}$ diff & DFDI & -2.351 & $-3.661^{\star \star}$ & $-1.648^{*}$ & $-5.081^{\star \star \star}$ & $-6.416^{\star \star \star}$ & $-4.317^{\star \star \star}$ \\
\hline Level & LINVE & $2.735^{\star}$ & -0.033 & $4.035^{\star \star \star}$ & 2.614 & -0.143 & 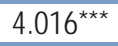 \\
\hline $1^{\text {st }}$ diff & DINVE & $-3.711^{\star \star \star}$ & $-6.135^{\star \star \star}$ & $-2.649 * \star \star$ & $-7.050^{* \star \star}$ & $-9.424^{\star \star \star}$ & $-5.884^{\star \star \star}$ \\
\hline Level & LREXCH & $-2.810^{*}$ & -3.019 & -0.824 & -2.174 & -2.535 & -0.614 \\
\hline $1^{\text {st }}$ diff & DREXCH & $-4.137^{\star \star \star}$ & $-4.158^{* *}$ & $-4.173^{\star \star \star}$ & $-4.814^{\star \star *}$ & $-4.836^{\star \star \star}$ & $-4.854^{\star \star \star}$ \\
\hline Level & LDEBT & -0.132 & -2.047 & 0.757 & 0.044 & -1.890 & 1.090 \\
\hline $1^{\text {st }}$ diff & DDEBT & $-3.588^{\star *}$ & $-3.735^{\star \star}$ & $-3.154^{\star \star *}$ & $-4.515^{\star \star \star}$ & $-4.581^{\star \star \star}$ & $-4.175^{\star \star \star}$ \\
\hline $1 \%$ & \multirow{3}{*}{ Critical value } & -3.679 & -4.310 & -2.647 & -3.679 & -4.310 & -2.647 \\
\hline $5 \%$ & & -2.968 & -3.574 & -1.952 & -2.968 & -3.574 & -1.953 \\
\hline $10 \%$ & & -2.623 & -3.222 & -1.610 & -2.623 & -3.221 & -1.610 \\
\hline
\end{tabular}

*** represents stationary at $1 \%$ level of significance

** represents stationary at $5 \%$ level of significance

* represents stationary at $10 \%$ level of significance

$L$ represents Logarithms of variables

$D$ represents that the variable has been differenced

Critical for ADF and PP is -3.574 at $5 \%$

Source: Own table with data from E views 7 iterations 
The results reported above were carried with both intercept and trend. Other deterministic trend assumptions were explored but did not yield better results. Under the assumptions of no intercept and trend in all cases and trend no intercept in some of the cases, the test statistics were insignificant, hence only the ones that produced better results were reported. The unit root tests using intercept and trend suggests that all series are non-stationary in level and becomes stationary after differencing. Thus the variables becomes integrated of order one, 1(1).

\subsection{Cointegration Test}

This study employs the Johansen's (Johansen and Juselius 1990) maximum likelihood approach to test for cointegration. The pair- wise correlation matrix is adopted in this study to determine the exact relationship between the five variables used in the study. Results from the pair- wise correlation matrix are presented in Table 4.2 below.

Table 4.2: Pair-wise Correlation Results

\begin{tabular}{|lccccc|}
\hline \multicolumn{1}{|c}{ Variable } & RGDP & FDI & INVE & REXCH & DEBT \\
\hline RGDP & 1.000 & 0.767 & 0.642 & -0.323 & -0.272 \\
\hline FDI & 0.767 & 1.000 & 0.243 & -0.425 & -0.762 \\
\hline INVE & 0.642 & 0.241 & 1.000 & -0.262 & 0.1861 \\
\hline REXCH & -0.323 & -0.425 & -0.262 & 1.000 & 0.824 \\
\hline DEBT & -0.272 & -0.762 & 0.1861 & 0.824 & 1.000 \\
\hline
\end{tabular}

Source: Own table with data from E views 7 iterations.

From the pair-wise correlation results shown above, FDI and INVE are positively correlated with the dependent variable RGDP. FDI is highly correlated with RGDP than INVE. The positive correlation of both variables is in line with previously stated theoretical underpinnings. Theory suggests that an increase in foreign direct investment and domestic investment causes an increase in economic growth. This emanates from increased consumption expenditure, employment and capital outlay amongst several other positive effects (Moolman, et al, 2006).

REXCH and DEBT are negatively correlated with RGDP. This confirms theoretical suggestions, which propose that the depreciation in the exchange rate discourages investment. This translates into low levels of economic growth. On the same note, an increase in DEBT has a negative long run relationship with RGDP. The logic lies in the interest accrued in debt repayment. This suppresses the coffers that could have been channelled for further development (Moolman, et al, 2006).

In using the Johansen test, there is need to determine optimal lag length which eliminates serial -correlation in the residuals as well as determining the deterministic trend assumptions for the VAR model. To select the lag order for the VAR, the information criteria approach is applied as a direction in choosing lag order. A maximum of 3 lags is utilised in order to permit adjustment in the model and accomplish well behaved residuals. Table 4.3 confirms the lag lengths selected by different information criteria.

Table 4.3 Lag Order Selection Criteria

\begin{tabular}{ccccccc} 
Lag & LogL & LR & FPE & AIC & SC & HQ \\
\hline \hline 0 & 66.87453 & NA & $1.32 \mathrm{e}-07$ & -4.491038 & -4.300723 & -4.432857 \\
1 & 145.0930 & $128.5018^{*}$ & $1.57 \mathrm{e}-09^{*}$ & $-8.935215^{*}$ & $-7.983640^{*}$ & $-8.644309^{*}$ \\
2 & 159.9438 & 20.15467 & $1.85 \mathrm{e}-09$ & -8.853130 & -7.140296 & -8.329499 \\
3 & 174.8381 & 15.95820 & $2.47 \mathrm{e}-09$ & -8.774153 & -6.300059 & -8.017798 \\
\hline \hline
\end{tabular}

* indicates lag order selected by the criterion

LR: sequential modified LR test statistic (each test at $5 \%$ level)

FPE: Final prediction error

AIC: Akaike information criterion

SC: Schwarz information criterion

HQ: Hannan-Quinn information criterion

Table 4.3 above shows that all the criteria selected 1 lag. Therefore, the information criteria approach produced agreeing results and a decision to adopt 1 lag can be made. Subsequently, the Johansen cointegration test is conducted using 1 lag for the VAR. 
The Johansen cointegration based on the trace test is shown in Table 4.4 (a). The trace test the null hypothesis that the number of cointegrating equations is greater than the number of variables involved. The null hypothesis fails to be rejected if the test statistic is smaller than the critical values of the trace tests. Table 4.4(b) presents the results of the Johansen cointegration tests based on the maximum eigenvalue. The maximum eigenvalue test is conducted on the null hypothesis of the number of cointegrating equations $(r)$ against the alternative hypothesis of number of cointegrating equations plus one $(r+1)$. The null hypothesis cannot be rejected if the test statistic is smaller than the maximum eigenvalue test critical value.

Table 4.4 (a) Cointegration Rank Test (Trace) Unrestricted Cointegration Rank Test (Trace)

\begin{tabular}{|c|c|c|c|c|}
\hline $\begin{array}{c}\text { Hypothesized } \\
\text { No. of } \mathrm{CE}(\mathrm{s})\end{array}$ & Eigenvalue & $\begin{array}{c}\text { Trace } \\
\text { Statistic }\end{array}$ & $\begin{array}{c}0.05 \\
\text { Critical Value } \\
\end{array}$ & Prob. ** \\
\hline None * & 0.710715 & 84.23957 & 69.81889 & 0.0023 \\
\hline At most 1 * & 0.531279 & 48.26959 & 47.85613 & 0.0457 \\
\hline At most 2 & 0.403314 & 26.29489 & 29.79707 & 0.1201 \\
\hline At most 3 & 0.303432 & 11.32032 & 15.49471 & 0.1925 \\
\hline At most 4 & 0.028357 & 0.834232 & 3.841466 & 0.3611 \\
\hline
\end{tabular}

Trace test indicates 2 cointegratingeqn(s) at the 0.05 level

* denotes rejection of the hypothesis at the 0.05 level

**MacKinnon-Haug-Michelis (1999) p-values

Table 4.4 (b) Cointegration Rank Test (Maximum Eigenvalue)

Unrestricted Cointegration Rank Test (Maximum Eigenvalue)

\begin{tabular}{ccccc}
\hline \hline Hypothesized & \multicolumn{3}{c}{ Max-Eigen } & 0.05 \\
No. of CE(s) & Eigenvalue & Statistic & Critical Value & Prob.** \\
\hline \hline None ${ }^{*}$ & 0.710715 & 35.96998 & 33.87687 & 0.0277 \\
At most 1 & 0.531279 & 21.97470 & 27.58434 & 0.2217 \\
At most 2 & 0.403314 & 14.97457 & 21.13162 & 0.2907 \\
At most 3 & 0.303432 & 10.48609 & 14.26460 & 0.1819 \\
At most 4 & 0.028357 & 0.834232 & 3.841466 & 0.3611 \\
\hline \hline
\end{tabular}

Max-eigenvalue test indicates 1 cointegrating eqn(s) at the 0.05 level

* denotes rejection of the hypothesis at the 0.05 level

**MacKinnon-Haug-Michelis (1999) p-values

The trace test which is much stricter reflected that at least two cointegrating equations exist at 5 per cent significance level. The null hypothesis of no cointegrating vectors and at most 1 is rejected since the trace (test) statistic of 84.24 and 48.27 is greater than the 5 per cent critical value of approximately 69.82 and 47.86 respectively. Hence the trace statistics specified 2 cointegrating relationship at 5 per cent significance level.

The maximum eigenvalue test in Table 4.4 (b) reveals that at least one cointegrating equation exists at 5 per cent significance level. The null hypothesis of no cointegrating vectors is rejected since the eigenvalue of 35.97 is greater than the 5 per cent critical value of about 33.88. Using the same analysis, the null hypothesis that there is at most one cointegrating vector cannot be rejected since the test statistic of 21.98 is less than the 5 per cent critical value of 27.58 . Therefore it can be concluded that there are two significant long run relationships between the variables using the trace test. Since variables can either have short or long run effects, a vector error correction model (VECM) was used to disaggregate these effects.

A summary of results in Table 4.4 (a) shows the existence of two cointegrating equations. Trace test and the maximum eigenvalue test evidently generate conflicting results. In such a situation Johansen and Juselius (1990) advises the examination of the cointegrating vector and base the decision on the interpretability of the cointegrating relations.

Luintel and Khan (1999:32) reiterated that, it is essential to use results of both tests. In this regard, the choice of the cointegration rank should be guided by prior theoretical information.

Batchelor (2000:12) in turn suggests that, in the presence of two cointegrating equations, there is need for normalization of the cointegrating coefficients. The normalization process yields one cointegration equation and one cointegration vector. Bartchelor's approach is adopted in the study.

The cointegration vector represents the deviations of the endogenous variable from its long run equilibrium level. 
Figure 4.1 suggests that from 1980 to 2010 the deviations of RGDP from equilibrium were stationary. This is critical for its use as an error correction model.

Figure 4.1 Cointegrating Vector

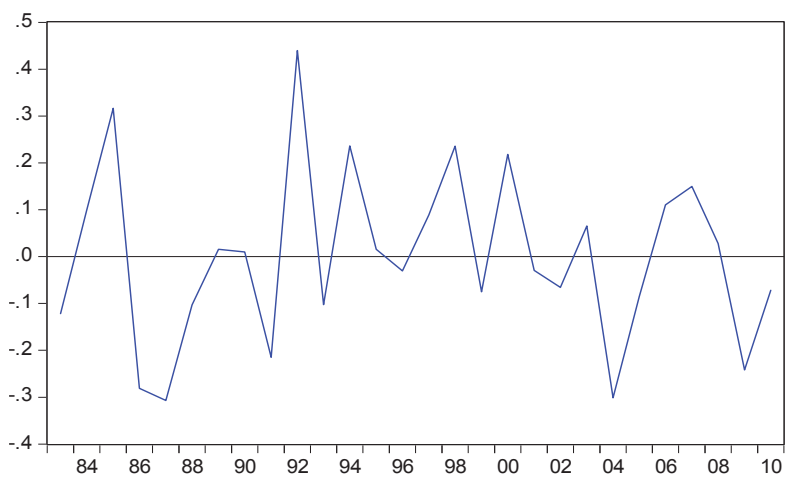

Source: Eviews 7 Computation: Data from SARB, 2011

\subsection{Vector Error Correction Model}

The discovery of at least one cointegration equation in the previous section implies that a VECM can be used. This allows us to distinguish between the short and long run effects of variables so as to establish the effect of foreign direct investment on economic growth.

Assumption three of using intercept and no trend was used in the model. Other deterministic assumptions were explored but did not yield interpretable results. Section 4.3.1 and 4.3.2 presents results of the VECM over the Long run and Short run period.

\subsubsection{Long Run Terms}

Summary of the long run parameters in the model is reported in Table 4.5 below.

Table 4.5 Results of Long Run Cointegration Equation

\begin{tabular}{|lccc|}
\hline Variable & Coefficient & Standard error & t-statistic \\
\hline Constant & 4.660 & - & - \\
\hline RGDP & 1.00 & - & - \\
\hline FDI & -0.539 & 0.113 & -4.776 \\
\hline INVE & 0.782 & 0.181 & 4.325 \\
\hline REXCH & -2.799 & 0.424 & -6.604 \\
\hline DEBT & -0.544 & 0.091 & -5.959 \\
\hline
\end{tabular}

Source: Own table with data from Eviews 7: VECM assumption 3

The long run impact of the explanatory variables on RGDP as shown by table 4.5 is illustrated using equation 5.1 :

RGDP $=4.660-0.539 \mathrm{FDI}+0.782 \mathrm{INVE}-2.799 \mathrm{REXCH}-0.544 \mathrm{DEBT}$.

Equation 5.1 shows that FDI, REXCH and DEBT have a negative long run relationship with RGDP. INVE has a positive impact on RGDP. All the explanatory variables are statistically significant in explaining RGDP since they have absolute t-values greater than 2 .

A unit increase in FDI causes a decrease in RGDP by 53.9 per cent. This is not compatible with theory. In theoretical suggestions, FDI causes an increase in economic growth. This emanates from the spill-over effects in capital, technology and an increase in production. Reasons for this phenomenon could have been attributed to the recent emergence of the global financial crisis. The global financial crisis originated in the US in 2010. 
Firsher (1936:158) defines the financial crisis as a disruption to world trade due to the inefficient allocation of capital resources. As a result, there is impediment in the flow of investment. The implications of the financial crisis are still crippling major foreign investment economies.

A unit increase in domestic investment results in an increase in RGDP by 78.2 per cent. The relationship is consistent with theory. Domestic investment has been curtailed by the ease of credit availability from the financial sector. This emanates from the fact that a more developed financial sector would entail transparency in the financial system. This has implications of increased domestic investment. Hence a positive relationship with RGDP is ensued (Khaliq and Noy, 2007).

Real effective exchange rate has a negative long run relationship with RGDP in the model. The t-value, -6.60 is significant at 5 per cent level. The result is plausible since an appreciation in the exchange rate, may result in increase in RGDP. The rationale is that strong currency translates local currency profits into large foreign currency profits. A unit increase in real exchange rate will result in 2.7 per cent decrease in RGDP.

Debt which is a measure of total loan debt of national government is found to be significant and negatively related to RGDP. This is portrayed by a t value of -5.96 at 5 per cent level of significance. A unit increase in debt reduces RGDP by 54.4 per cent. This is compatible with economic theory. In theoretical suggestions, developing countries have somewhat relied on debt to aid their economic activities. This has a negative implication on economic growth in the long run as finances meant for economic development are channelled towards repayment of interest accrued debt.

\subsubsection{Speed of Adjustment and Short Run Terms}

The speed of adjustment is indicated by the coefficients of the error correction terms. Results from the error correction model are presented in Table 4.6.

Table 4.6 Vector Error Correction Results

\begin{tabular}{|lccc|}
\hline \multicolumn{1}{|c}{ Variable } & Coefficient & Standard Error & t-statistic \\
\hline RGDP & -0.285 & 0.146 & -1.168 \\
\hline FDI & 0.863 & 0.643 & -1.765 \\
\hline INVE & -0.756 & 0.701 & -1.078 \\
\hline REXCH & 0.449 & 0.204 & 2.195 \\
\hline DEBT & -0.667 & 0.402 & -1.658 \\
\hline
\end{tabular}

Source: VECM results using data sourced from SARB, 2011

Using results from table 4.6, the coefficient of $D$ (RGDP) is reported as -0.285 . This shows that the speed of adjustment is approximately 28.5 per cent. The implication is that, if there is a deviation from equilibrium, only 28.5 per cent is corrected in one year as the variable moves towards restoring equilibrium. Thus, there is no strong pressure on RGDP to restore long run equilibrium whenever there is a disturbance. The speed of adjustment is statistically significant with a negative tvalue of -1.168 .

The low speed of adjustment by RGDP may reflect the existence of some factors affecting RGDP in South Africa other than FDI. These factors include level of education connoted as human capital, consumer price index, imports and exports, amongst others.

The lag of LFDI is found to have a positive effect on RGDP in the short-run. However the t- value of -1.765 is insignificant. The coefficient shows that current RGDP can increase by 86.3 per cent if LFDI is increased by 1 per cent. This shows that the exogenous component of FDI exerts a reliable, positive impact on economic growth.

The error term, which has been included to take into account all factors that affects RGDP but were not taken into account explicitly, was found to be insignificant. Despite its insignificance, the usage of the error term made rightful contribution in determination of the cointegrating relationship in the model. Thus, a model with an error term is preferred to a model without an error term.

\subsection{Diagnostic Tests}

The fitness of the model was tested in three main ways. Firstly heteroscedasticity was tested using White's test with no cross terms. This was followed by Jarque-Bera's normality test. Finally serial correlation was tested using the Langrage 
multiplier (LM) test. The Diagnostic test results are shown in Table 4.7.

Table 4.7 Diagnostic Test Results

\begin{tabular}{|l|c|c|c|}
\hline \multicolumn{1}{|c|}{ Test } & Null Hypothesis & t-Statistic & Probability \\
\hline White (Chi-sq.) & No conditional heteroscedasticity & 319.086 & 0.215 \\
\hline Jarque-Bera & There is normal distribution & 13.779 & 0.183 \\
\hline Langrage Multiplier (LM) & No Serial Correlation & 30.623 & 0.702 \\
\hline
\end{tabular}

Source: Diagnostic test results using data sourced from SARB, 2011

\subsubsection{Heteroscedasticity}

Results from Table 4.7 shows that the test for heteroscedasticity using White test with no cross-terms produced a Ch-sq of 319.086 at a probability of 0.215 . The presence of heteroscedasticity means the model has some misspecifications hence conclusive results cannot be derived from such a model. The null hypothesis of no heteroscedasticity or no misspecification will thus not be rejected. This implies that the model has no misspecifications and can be relied on.

\subsubsection{Residual Normality Test}

Normality tests were carried using the Jarque -Bera (J-B) test. The J-B statistic follows the chi-square distribution with $2 d . f$. If the computed $p$ value of the J-B is sufficiently low, which will happen if the value of the test statistic is different from 0 , one can reject the hypothesis that the residuals are normally distributed. If the $p$ value is high, that is when the value of the test statistic is close to 0; we do not reject the normality assumption (Gujarati, 2004:148).

Based on results from Table 4.7, the Jarque- Bera statistic of 13.779 with a probability of 0.183 indicates the rejection of the null hypothesis at 5 per cent significance level. This shows that residuals are not normally distributed. According to Harris (1995:83), non-normality in the residuals is not a problem. The argument stems from the fact that some variables are weakly exogenous. In the model weakly exogenous variables include FDI, REXCH and DEBT.

\subsubsection{Autocorrelation Langrage Multiplier (LM) Test}

The problem of serial correlation arises when a variable has relationships with itself in a manner that the value of such a variable in past periods has an effect on its future values (Gujarati, 2004:680).

The results reported in Table 4.7 show that the test for serial correlation produced an LM statistic of 30.623 with a probability of 0.702 . This suggests that we cannot reject the null hypothesis of no serial correlation due to high probability.

The diagnostic checks have all revealed the suitability of the model. Thus, compelling conclusions on the effect of foreign direct investment on economic growth can be deduced and applicable policies can be safely formulated.

\subsection{Impulse Response Analysis}

These impulse response functions show the dynamic response of RGDP to a one- period standard deviation shock to the innovations of the system and also indicate the directions and persistence of the response to each of the shocks over a 10 year period. The impulse response functions have the expected pattern and confirm the results from the short-run relationship analysis. Shocks to all the variables are significant but not persistent. The results of the variance decomposition analysis are presented in Figure 4.2. 
Figure 4.2: Impulse Response Results
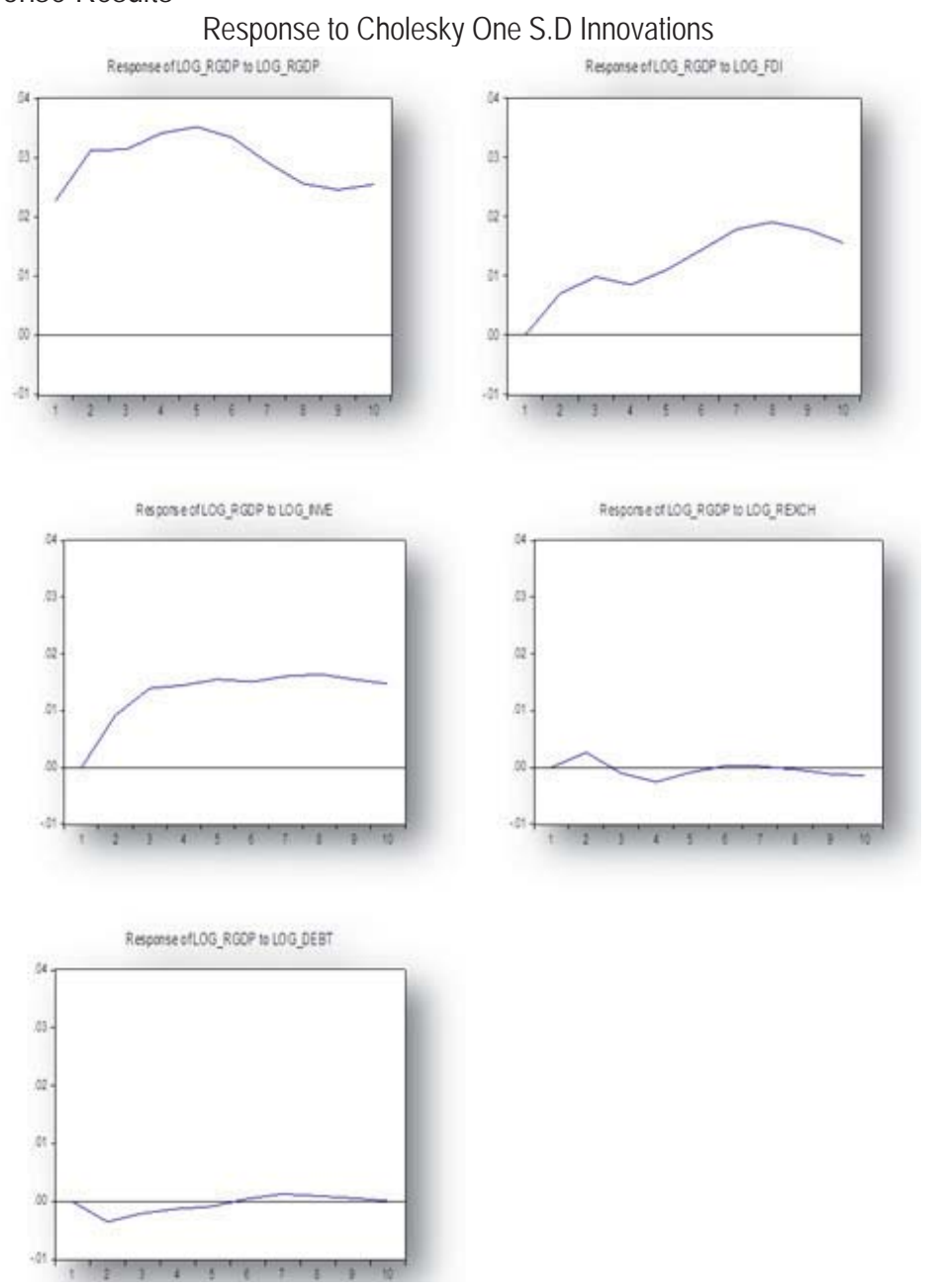

In the results of the model above, one period standard deviation shock on RGDP produces a large positive impact on itself by nearly 4 per cent. This is persistent from the first to the fifth year. The shocks die off becoming negative from the sixth to the tenth year.

Innovations on FDI shows a positive impact which rises gradually during the first three years and continues to be persistent in the sixth year to the tenth year. The signs are consistent with signs on short run parameters.

A one- period shock to INVE has a lasting positive impact on RGDP. The shock appreciates RGDP by nearly 2 per cent and dies off in the sixth year onwards.

Shocks on REXCH, and DEBT generates a negative response on RGDP. The shocks are not significantly different from zero and are transitory. The signs are consistent with findings on long run parameters. Either sign could apply on REXCH and RGDP relationship since there is no consensus on the correct sign. This usually depends on which sign has a larger impact at a particular point in time. It takes a period of six years for REXCH to adjust towards equilibrium. A shock on DEBT has a marginal depreciation effect on RGDP. The shock fluctuates below 1 per cent. The adjustment towards the equilibrium is visible mid- way through the sixth year.

\subsection{Variance Decomposition Analysis}

Variance decomposition analysis indicates the proportion of the movements in a sequence due to its own shocks versus shocks to other variables. It shows the fraction of the forecast error variance for each variable that is attributable to its innovations and innovations in the other variables in the system. The results of the variance decomposition analysis are presented in Table 4.8 and these show the proportion of the forecast error variance in RGDP explained by its own innovations and innovations in explanatory variables. 
Table 4.8 Variance Decomposition of RGDP

\begin{tabular}{|c|c|c|c|c|c|c|}
\hline Period & S.E. & RGDP & FDI & INVE & REXCH & DEBT \\
\hline $\mathbf{1}$ & 0.02435 & 100.0000 & 0.000000 & 0.000000 & 0.000000 & 0.000000 \\
\hline $\mathbf{2}$ & 0.04462 & 85.75977 & 11.33033 & 0.562735 & 0.004200 & 2.342966 \\
\hline $\mathbf{3}$ & 0.05283 & 83.55162 & 8.606726 & 1.673914 & 1.467766 & 4.699976 \\
\hline $\mathbf{4}$ & 0.05698 & 81.91474 & 6.442034 & 1.808133 & 4.346770 & 5.488325 \\
\hline $\mathbf{5}$ & 0.06941 & 76.80461 & 5.816499 & 1.492371 & 7.857144 & 8.029375 \\
\hline $\mathbf{6}$ & 0.10872 & 69.95331 & 6.339770 & 1.457896 & 11.25300 & 10.99603 \\
\hline $\mathbf{7}$ & 0.12594 & 65.07803 & 8.524421 & 1.327301 & 13.69006 & 11.38019 \\
\hline $\mathbf{8}$ & 0.14296 & 61.27560 & 10.92748 & 1.170047 & 15.65180 & 10.97507 \\
\hline $\mathbf{9}$ & 0.15780 & 58.78849 & 12.62958 & 1.076705 & 16.99922 & 10.50600 \\
\hline $\mathbf{1 0}$ & 0.17992 & 57.37252 & 14.01024 & 1.011529 & 17.53535 & 10.07037 \\
\hline
\end{tabular}

Source: Variance decomposition results using data from SARB, 2011

The variance decomposition analysis above covers a period of 10 years in order to ascertain the effects when the variables were allowed to affect RGDP for a relatively longer time.

In the first year, all of the variance in RGDP is explained by its own innovations, this is as suggested by Brooks (2002:342).

For the $5^{\text {th }}$ year ahead forecast error variance, RGDP explains about 77 per cent of its variation. This is consistent with impulse response results. Explanatory variables account for 23 per cent of the error variance. FDI explains 6 per cent, INVE about 1 per cent, REXCH about 8 per cent and DEBT 8 per cent.

After a period of 10 years, RGDP explains about 57 per cent of its own variation. Explanatory variables explain the remaining 43 per cent. The influence of FDI increases substantially to about 14 per cent. INVE remain at 1 per cent. REXCH increases to about 18 per cent. This explains the largest component of the 43 per cent variation in RGDP that is explained by the explanatory variables. DEBT increases slightly to 10 per cent.

The variance decomposition analysis results are compatible with economic theory. Shocks to the explanatory variables continued to explain a significant proportion of the variation in RGDP. This is consistent with results from the impulse response analysis.

\section{Conclusions and Policy Recommendations}

The findings imply that foreign direct investment does not exert reliable impact on economic growth. This was after taking consideration of the long-run results. In the short-run, foreign direct investment causes a positive impact on economic growth whilst crowding-out domestic investment.

The results from the findings imply that the policies and incentives implemented by the government could have had little impact of attracting foreign direct investment that could enhance a significant impact economic growth in the longrun. This would however verily support Solow growth model which suggests that, FDI enables host countries to achieve investment that exceeds their own domestic saving and enhances capital formation. According to this theory, the potential beneficial impact of FDI on output growth is confined to the short-run. In the long run, given the diminishing marginal returns to physical capital, the recipient economy could converge to the steady state growth rate as if FDI has never taken place leaving no permanent impact on the growth of the economy (De Mello, 1997).

On the other hand, the New Endogenous growth model which is modern highlight the importance of improvement in technology, efficiency and productivity in suggesting that FDI can positively influence the growth rate in so far as it generates increasing returns in production via externalities and production spill-overs. This is supported by the fact that, with an increase in the pace of globalization that resulted partly from liberalization of trade and exchange rate regimes, the volume of FDI has increased throughout the world. South Africa is not spurred in this phenomenon. However, the results of the long- run parameters confirmed the opposite in entailing that FDI has a negative impact on economic growth. The reason could be attributed to a shift in FDI from the traditional manufacturing sector towards the more efficient green- field investments and service sector. Results from the sectoral analysis reviewed in chapter three highlight such changes.

Sectoral analysis indicated that the financial sector is now the major recipient of FDI to South Africa. This suggests the possibility of a shift in FDI motives from natural resource seeking and market seeking FDI to efficiency seeking FDI. 
This is confirmed by increased role of the services sector in FDI. Evidence in support of this supposition is shown by the increase in mergers and acquisitions as opposed to green-field investment. FDI policy for the financial and services sectors need to be targeted to efficiency seeking FDI. FDI should also be encouraged in other sectors of the economy in order to diversify and increase total inflows.

South Africa needs to maintain strong bi-lateral agreements signed with various trade partners. For instance, the BRICS (Brazil-Russia-India-China-South Africa) initiative in 2010 produced widespread increase in FDI in South Africa. This was despite the insurgence of the global financial crisis during the same period.

As discussed in the ICDT (International Centre for Tax and Development) annual centre meeting in 2012, incentives to lure foreign direct investment have negative implications which are distortionary within the economy. This is brought about by the complexities involved in designing effective incentive structures and weaker administrative capacities of the country. Hence the appropriate fiscal policy would be of a simple tax system with low rates. The tax system should not discriminate between foreign and domestic investors. Furthermore, the corporate tax rates should be congruent to those in capital exporting countries.

Lowering corporate tax rates, ensuring property rights, relaxation of exchange control regulations and lowering real wages serves as other policy measures meant to increase foreign direct investment in South Africa. The implications would be an increase in FDI, which will then excel into economic growth.

\section{References}

Alfaro, L., Chanda, A., Ozcan, S.K., Sayek, S. (2006). "How Does Foreign Direct Investment Promote Economic Growth? Exploring the Effects of Financial Markets on Linkages." National Bureau of Economic Research, Working paper 12522. Cambridge, MA.

Apergis, N, Lyroudi, K., Vamvakidis, T. (2006). The Relationship between Foreign Direct Investment and Economic Growth: Evidence from Transitional Countries. [Online] Available: http://ssrn.com/abstract=990251, (Accessed 20 October 2012).

Asiedu, E. (2002). On the determinants of FDI to developing countries: Is Africa different? World Development 30 (1), 107-119.

Bartchelor, R. (2000). E -Views Tutorial 2: Cointegration and Error Correction, City University Business School: London.

Borensztein, E., Gregorio, J., and Lee J. (1998). How does foreign direct investment affect economic growth? Journal of International Economics 45, 115 135.

Brooks, C. (2002). Introductory Econometrics for Finance (6e), Cambridge University Press

Burda, M., Wyploszy, C. (2001). Macroeconomica European Text (3e). New York: Oxford University press Inc.

Caner, M., Hansen, B. (2004). Econometric Theory 20, 813-843.

Carkovic, M., Levine, R. (2002). Does Foreign Direct Investment Accelerate Economic Growth? Department of Business Finance, University of Minessota, Working paper Series.

Chakrabarti, A. (2001).The Determinants of Foreign Direct Investment: Sensitivity Analysis of Cross-Country Regressions. KYKLOS 54, 89-112.

De Mello, L.R. (1997). Foreign Direct Investment in Developing Countries and Growth: A Selective Survey", Journal of Development Studies, 34 (1), 115135.

EViews 7 User's Guide II. (2009). Quantitative Micro Software, Irvine, CA.

Fedderke, J.W., Romm, A.T. (2004). Growth Impact and determinants of foreign direct investment into South Africa. University of Cape Town. Working Paper: 12.

Gujarati, D.N. (2004). Basic econometrics- $4^{\text {th }}$ edition, New York: McGraw- Hill International Editions, Economic Series.

Harris, R.J.D. (1995). Using Cointegration Analysis in Econometric Modelling, Harvester Wheatsheaf: Prentice Hall.

Harrord, R. (1939). An Essay in Dynamic Theory. Economic Journal 3, 14-33.

Huang, H.C., Chang, Y.K. (2004). Trade Threshold Variable for Multiple Regimes? Working paper, Tamkang University, Taiwan.

Human Development Report (HDR). (2009). United Nations Development program, Journal of Economics 32 (2), 12-46.

International Centre for Tax and Development (ICDT). (2012). Meeting on Africa's tax structure and fiscal incentives impact on investment. Cape Town, South Africa.

International Monetary Fund (IMF). (2011). New Growth Drivers for Low- Income Countries: The Role of BRICSs, Washington.

Johansen, S., and Juselius, K. (1990). Maximum likelihood estimation and inference on Cointegration with applications to the demand for money. Oxford Bulletin of Economics and Statistics 52 (2): 169-210.

Johansen, S. (1995). Likelihood based inference in Cointegrated Vector Autoregressive Models. New York, Oxford University Press.

Johansen, S. (1998). Statistical analysis of cointegration vectors. Journal of Economic Dynamics and Control 12, 231-254.

Jyun-Yi, Wu., and Hsu Chih-Chiang. (2008). "Does Foreign Direct Investment Promote Economic Growth? Evidence from a Threshold Regression Analysis. Economics Bulleting 15 12, 1-10.

Kearney, M., and Quantec, O. (2011). Assessing Development Strategies to Achieve the MDGs in the republic of South Africa. United Nations Department for Social and Economic Affairs;

Khaliq, A., and Noy, I. (2007). Foreign Direct Investment and Economic Growth: Empirical Evidence from Sectoral Data in Indonesia, "Working Paper 200726, University of Hawaii, Manoa.

Lloyd, M. (1999). Public and Private Investment in the European Union: Working Papers of European Parliament, Luxembourg.

Louzi, B.M., and Abadi, A. (2011). The effect of Foreign Direct Investment on Economic Growth: IJRAAS Journal of Economics 8, 2-16.

Luintel, K. B., and Khan, M. (1999). A quantitative reassessment of the finance-growth nexus, Evidence from a multivariate VAR, Journal of Development Economics 60, 381-405.

Lutkepohl, H. (1993). Introduction to Multiple Time Series Analysis: Springer, Berlin.

Lyroudi, K., Papanastasiou, A., and Vamvakidis, A. (2004). The Importance of FDI on Economic Growth: Evidence from Transition Economies, SouthEastern Europe Journal of Economics 1, 97-110.

Moolman, C.E, Roos, E.L, Le roux, J.C., and Du toit, C.B. (2006). Foreign Direct Investment: South Africa's Elixir of life? University of Pretoria Working 
Paper, Pretoria.

Pradhan, R.P. (2011). The effect of FDI on trade-led growth hypothesis: a co-integrated panel analysis. International Journal of Green Economics 5 (3), 306. Presidential Commission. (1998). Restructuring of the South African Labour Market, Directorate of Communication 4, 18-42.

Romer, P. (1993). Idea gaps and objects gaps in economic development, Journal of Monetary Economics 32, 543-573.

Romer, P.M. (1993).Two Strategies for Economic Development: Using Ideas and Producing Ideas. In: Proceedings of the World Bank Annual Conference on Development Economics, 1992. Washington, DC: World Bank.

Sridharan, P., Vijayakumar, N., and Chandra S. R. (2009). Causal Relationship between Foreign Direct Investment and Growth: Evidence from BRICS Countries. International Business Research 2(4), 1-40.

Statistics South Africa. (2010). Census 2010 Labour Force survey, Quarterly Bulletins, South Africa Statistics, Pretoria.

World Investment Report (WIR). (2011). Global Investment Trends: United Nations Conference on Trade and Development, Geneva.

Xavier, C. (1994). Southern African Perspectives. Centre for Southern African Studies, University of the Western Cape, Cape Town.

\section{Appendix}

A.4 (a) Vector Error Correction Estimates Assumption 3

\begin{tabular}{|c|c|c|c|c|c|}
\hline \multicolumn{6}{|c|}{ Vector Error Correction Estimates } \\
\hline \multicolumn{6}{|c|}{ Date: 12/13/12 Time: $13: 35$} \\
\hline \multicolumn{6}{|c|}{ Sample (adjusted): 19832010} \\
\hline \multicolumn{6}{|c|}{ Included observations: 28 after adjustments } \\
\hline \multicolumn{6}{|c|}{ Standard errors in ( ) \& t-statistics in [] } \\
\hline Cointegrating Eq: & CointEq1 & & & & \\
\hline LOG_RGDP(-1) & 1.000000 & & & & \\
\hline \multirow[t]{3}{*}{ LOG_FDI(-1) } & -0.539020 & & & & \\
\hline & $(0.11286)$ & & & & \\
\hline & {$[-4.77617]$} & & & & \\
\hline \multirow[t]{3}{*}{ LOG_INVE(-1) } & 0.781830 & & & & \\
\hline & $(0.18076)$ & & & & \\
\hline & {$[4.32531]$} & & & & \\
\hline \multirow[t]{3}{*}{ LOG_REXCH(-1) } & -2.799633 & & & & \\
\hline & $(0.42393)$ & & & & \\
\hline & {$[-6.60406]$} & & & & \\
\hline \multirow[t]{3}{*}{ LOG_DEBT(-1) } & -0.543702 & & & & \\
\hline & $(0.09124)$ & & & & \\
\hline & {$[-5.95912]$} & & & & \\
\hline C & 4.660265 & & & & \\
\hline Error Correction: & $\mathrm{D}($ LOGRGDP) & D(LOG_FDI) & D(LOG_INVE) & D(LOG_REXCH) & D(LOG_DEBT) \\
\hline \multirow[t]{3}{*}{ CointEq1 } & -0.28583 & 0.863236 & -0.755997 & 0.448601 & -0.666608 \\
\hline & $(0.14608)$ & $(0.64321)$ & $(0.70120)$ & $(0.20442)$ & $(0.40204)$ \\
\hline & {$[-1.16828]$} & {$[-1.7654]$} & {$[-1.07814]$} & [2.19450] & {$[-1.65806]$} \\
\hline \multirow[t]{3}{*}{ D(LOG_RGDP(-1)) } & 0.332132 & -4.188927 & -4.548341 & 0.047878 & -3.168930 \\
\hline & $(0.21784)$ & $(2.84127)$ & $(3.31466)$ & $(0.96632)$ & $(1.90049)$ \\
\hline & [1.52464] & [-1.47431] & {$[-1.37219]$} & {$[0.04955]$} & {$[-1.66743]$} \\
\hline \multirow[t]{3}{*}{ D(LOG_RGDP(-2)) } & 0.191571 & 0.086545 & 2.038260 & 1.217609 & -1.903767 \\
\hline & $(0.22647)$ & $(2.95375)$ & (3.44588) & $(1.00457)$ & $(1.97573)$ \\
\hline & [0.84591] & [0.02930] & [0.59151] & [1.21207] & {$[-0.96358]$} \\
\hline \multirow[t]{3}{*}{ D(LOG_FDI(-1)) } & -0.029336 & -0.740203 & -0.046815 & 0.180825 & -0.103860 \\
\hline & $(0.03219)$ & $(0.41985)$ & $(0.48980)$ & $(0.14279)$ & $(0.28083)$ \\
\hline & {$[-0.91132]$} & {$[-1.76301]$} & {$[-0.09558]$} & [1.26635] & {$[-0.36983]$} \\
\hline \multirow[t]{3}{*}{ D(LOG_FDI(-2)) } & 0.009341 & -0.244937 & 0.068563 & 0.035325 & 0.366168 \\
\hline & $(0.02309)$ & $(0.30121)$ & $(0.35140)$ & $(0.10244)$ & $(0.20148)$ \\
\hline & [0.40447] & {$[-0.81317]$} & [0.19512] & [0.34483] & [1.81742] \\
\hline \multirow[t]{3}{*}{$\mathrm{D}\left(\mathrm{LOG} \_I N V E(-1)\right)$} & 0.044220 & 0.703393 & -0.422807 & -0.194475 & 0.405814 \\
\hline & $(0.02789)$ & $(0.36374)$ & $(0.42434)$ & $(0.12371)$ & $(0.24330)$ \\
\hline & [1.58562] & [1.93378] & {$[-0.99638]$} & {$[-1.57205]$} & [1.66795] \\
\hline \multirow[t]{3}{*}{ D(LOG_INVE(-2)) } & 0.028832 & 0.358059 & -0.051289 & 0.002377 & 0.129012 \\
\hline & $(0.01976)$ & $(0.25777)$ & $(0.30071)$ & $(0.08767)$ & $(0.17242)$ \\
\hline & [ 1.45886$]$ & [1.38908] & {$[-0.17056]$} & {$[0.02712]$} & [0.74825] \\
\hline \multirow[t]{3}{*}{ D(LOG_REXCH(-1)) } & -0.037377 & -2.539474 & -0.229236 & 0.701363 & -0.302099 \\
\hline & $(0.09962)$ & $(1.29936)$ & $(1.51585)$ & $(0.44191)$ & $(0.86913)$ \\
\hline & {$[-0.37519]$} & {$[-1.95441]$} & {$[-0.15123]$} & [1.58711] & {$[-0.34759]$} \\
\hline D(LOG_REXCH(-2)) & -0.058120 & -0.008315 & -0.551072 & 0.088913 & -0.272931 \\
\hline
\end{tabular}




\begin{tabular}{|c|c|c|c|c|c|}
\hline & $(0.06724)$ & $(0.87701)$ & $(1.02313)$ & $(0.29827)$ & $(0.58662)$ \\
\hline & {$[-0.86436]$} & {$[-0.00948]$} & {$[-0.53862]$} & [0.29810] & {$[-0.46526]$} \\
\hline \multirow[t]{3}{*}{ D(LOG_DEBT(-1)) } & -0.026023 & -0.950931 & -0.106825 & 0.160477 & -0.140556 \\
\hline & $(0.03419)$ & $(0.44597)$ & $(0.52027)$ & $(0.15167)$ & $(0.29830)$ \\
\hline & {$[-0.76107]$} & {$[-2.13227]$} & {$[-0.20533]$} & [ 1.05803] & {$[-0.47118]$} \\
\hline \multirow[t]{3}{*}{ D(LOG_DEBT(-2)) } & -0.013218 & -0.422715 & 0.113776 & 0.149512 & -0.122001 \\
\hline & $(0.02587)$ & $(0.33740)$ & $(0.39362)$ & $(0.11475)$ & $(0.22569)$ \\
\hline & {$[-0.51097]$} & {$[-1.25284]$} & [0.28905] & [1.30292] & {$[-0.54058]$} \\
\hline \multirow[t]{3}{*}{ C } & 0.017388 & 0.519108 & 0.258411 & -0.109559 & 0.284761 \\
\hline & $(0.01589)$ & $(0.20727)$ & $(0.24181)$ & $(0.07049)$ & $(0.13864)$ \\
\hline & [1.09413] & [2.50448] & [1.06867] & {$[-1.55417]$} & [ 2.05393] \\
\hline R-squared & 0.603291 & 0.378045 & 0.440931 & 0.461551 & 0.706624 \\
\hline Adj. R-squared & 0.330553 & -0.049549 & 0.056571 & 0.091367 & 0.504929 \\
\hline Sum sq. resids & 0.006651 & 1.131516 & 1.539971 & 0.130880 & 0.506253 \\
\hline S.E. equation & 0.020389 & 0.265932 & 0.310239 & 0.090443 & 0.177879 \\
\hline F-statistic & 2.211980 & 0.884121 & 1.147184 & 1.246816 & 3.503417 \\
\hline Log likelihood & 77.10138 & 5.190770 & 0.875891 & 35.38921 & 16.45064 \\
\hline Akaike AIC & -4.650099 & 0.486374 & 0.794579 & -1.670658 & -0.317903 \\
\hline Schwarz SC & -4.079154 & 1.057318 & 1.365524 & -1.099713 & 0.253042 \\
\hline Mean dependent & 0.038438 & 0.148030 & 0.122626 & -0.007198 & 0.150148 \\
\hline S.D. dependent & 0.024920 & 0.259579 & 0.319405 & 0.094882 & 0.252808 \\
\hline \multicolumn{2}{|c|}{ Determinant resid covariance (dof adj.) } & $1.87 \mathrm{E}-10$ & & & \\
\hline \multicolumn{2}{|c|}{ Determinant resid covariance } & 1.14E-11 & & & \\
\hline \multicolumn{2}{|l|}{ Log likelihood } & 154.0842 & & & \\
\hline \multicolumn{2}{|c|}{ Akaike information criterion } & -6.363157 & & & \\
\hline \multicolumn{2}{|l|}{ Schwarz criterion } & -3.270540 & & & \\
\hline
\end{tabular}

A.4 (b) Data used in Regression Analysis

\begin{tabular}{|c|c|c|c|c|c|}
\hline YEAR & RGDP & FDI & INVE & REXCH & DEBT \\
\hline 1980 & 122264 & 12273 & 2955 & 133.9 & 603 \\
\hline 1981 & 128658 & 14188 & 3787 & 144.88 & 894 \\
\hline 1982 & 131827 & 16092 & 4537 & 139.27 & 1328 \\
\hline 1983 & 136202 & 17075 & 4918 & 155.73 & 1362 \\
\hline 1984 & 141628 & 21830 & 4043 & 135.25 & 2327 \\
\hline 1985 & 143893 & 22760 & 4648 & 105.7 & 2754 \\
\hline 1986 & 147154 & 21451 & 4042 & 101.75 & 2530 \\
\hline 1987 & 152579 & 19327 & 3875 & 114.03 & 2267 \\
\hline 1988 & 155602 & 18422 & 3095 & 109.48 & 2399 \\
\hline 1989 & 158525 & 20433 & 3160 & 111.76 & 2033 \\
\hline 1990 & 158894 & 23602 & 4857 & 118.02 & 1956 \\
\hline 1991 & 161351 & 28004 & 2967 & 122.94 & 2099 \\
\hline 1992 & 162040 & 32552 & 6397 & 125.12 & 2367 \\
\hline 1993 & 162850 & 36334 & 6650 & 123.51 & 4996 \\
\hline 1994 & 168800 & 44701 & 11372 & 121.05 & 8058 \\
\hline 1995 & 174720 & 54764 & 13896 & 119.26 & 9610 \\
\hline 1996 & 186575 & 61976 & 13511 & 111.86 & 14259 \\
\hline 1997 & 195356 & 81463 & 15600 & 119.22 & 14647 \\
\hline 1998 & 199853 & 91862 & 18853 & 108.05 & 15842 \\
\hline 1999 & 210067 & 318630 & 23491 & 100.94 & 20025 \\
\hline 2000 & 216747 & 328859 & 38359 & 100 & 31118 \\
\hline 2001 & 234450 & 370695 & 50018 & 91.39 & 66619 \\
\hline 2002 & 249165 & 264419 & 31446 & 82.55 & 79877 \\
\hline 2003 & 261123 & 311208 & 84510 & 103.23 & 72617 \\
\hline 2004 & 279544 & 362858 & 79289 & 110.13 & 64207 \\
\hline 2005 & 295504 & 499586 & 81493 & 112.5 & 68787 \\
\hline 2006 & 324002 & 611722 & 85789 & 108.88 & 80326 \\
\hline 2007 & 349501 & 751925 & 96949 & 105.05 & 77608 \\
\hline 2008 & 375276 & 632619 & 103252 & 94.09 & 99171 \\
\hline 2009 & 378997 & 866664 & 113025 & 101.41 & 88088 \\
\hline 2010 & 386745 & 1015517 & 140584 & 113.85 & 88926 \\
\hline
\end{tabular}

